\title{
Antimicrobial Sensitivity Pattern of Pseudomonas fluorescens after Biofield Treatment
}

Trivedi $\mathbf{M K}{ }^{1}$, Patil $\mathbf{S}^{1}$, Shettigar $\mathbf{H}^{1}$, Gangwar $\mathbf{M}^{2}$ and Jana $\mathbf{S}^{2^{*}}$

${ }^{1}$ Trivedi Global Inc., 10624 S Eastern Avenue Suite A-969, Henderson, NV 89052, USA

${ }^{2}$ Trivedi Science Research Laboratory Pvt. Ltd., Hall-A, Chinar Mega Mall, Chinar Fortune City, Hoshangabad Rd., Bhopal- 462026 Madhya Pradesh, India

"Corresponding author: Snehasis Jana, Trivedi Science Research Laboratory Pvt. Ltd., Hall-A, Chinar Mega Mall, Chinar Fortune City, Hoshangabad Rd., Bhopal462026 Madhya Pradesh, India, Tel: +91-755-6660006; E-mail: publication@trivedisrl.com

Received date: June 18, 2015; Accepted date: June 27, 2015; Published date: July 4, 2015

Copyright: (c) 2015 Trivedi. This is an open-access article distributed under the terms of the Creative Commons Attribution License, which permits unrestricted use, distribution, and reproduction in any medium, provided the original author and source are credited.

\begin{abstract}
Global emergence of Pseudomonas fluorescens ( $P$. fluorescens) displays a mechanism of resistance to all existing antimicrobials. Due to its strong ability to acquire resistance, there is a need of some alternative treatment strategy. Objective of this study was to investigate the effect of biofield treatment on antimicrobial sensitivity pattern of $P$. fluorescens. P. fluorescens cells were procured from MicroBioLogics in sealed packs bearing the American Type Culture Collection (ATCC 49838) number. Two sets of ATCC samples were taken in this experiment and denoted as A and B. ATCC-A sample was revived and divided into two groups (Gr) i.e. Gr.I (control) and Gr.II (revived); likewise, ATCC-B was labeled as Gr.III (lyophilized). Gr.II and III were given biofield treatment and were measured by MicroScan Walk-Away ${ }^{\circledR}$ system before and after treatment. Parameters studied in experiment were antimicrobial sensitivity, minimum inhibitory concentration (MIC), biochemical reactions, and biotype number of both control and treatment groups using MicroScan Walk-Away ${ }^{\circledR}$ system. Experimental results showed antimicrobials such as cefepime, cefotaxime, ceftazidime, ceftriaxone, ciprofloxacin, piperacillin, tetracycline, and tobramycin showed altered sensitivity and MIC values in treated group as compared to control. Biochemical reactions showed positive reaction in malonate, melibiose, nitrate, galactosidase, ornithine, raffinose, sorbitol, sucrose, tobramycin and Voges-Proskauer in Gr.II. Arabinose, colistin, glucose, and rhaminose also showed positive reactions in Gr.II on day 10 while arginine and cetrimide showed negative reaction in $\mathrm{Gr}$.III as compared to control. Biochemical tests results revealed a change in biotype number in Gr.II (34101173, day 5), (77103177, a very rare biotype on day 10$)$ and Gr.III (40000043) as compared to control (02041722). Organism was identified as Enterobacter cloacae (Grll, day 10) and Vibrio fluvialis (Gr.III, day 10) with respect to control. These findings suggest that biofield treatment made significant alteration in sensitivity pattern, MIC values, and biotype number of $P$. fluorescens.
\end{abstract}

Keywords: Pseudomonas fluorescens, Antibiotic susceptibility; Biofield treatment; Biochemical reactions; Biotyping

\section{Introduction}

Pseudomonas fluorescens ( $P$. fluorescens) is Gram negative, obligate aerobic, and considered as a psychrotrophic microorganism, unable to grow at temperatures above $32^{\circ} \mathrm{C}$. Fluorescent species of pseudomonas, initially considered to be nonpathogenic for human. Since 1953, human pathogenicity has been reported, when Pittman describes its presence and characteristics in blood and caused severe to fatal symptoms in infected patients [1]. P. fluorescens is an opportunistic pathogen, and able to inhabit in many environment like plants, soil, and water surfaces. Different clinical strains of $P$. fluorescens have been reported for high hemolytic activity, which induce cyctotoxic and proinflammatory responses in epithelial intestinal cells [2]. P. fluorescens also resides in the plant's rhizosphere and produces a variety of secondary metabolites including antibiotics against soil borne plant pathogens, but potential risk with $P$. fluorescens causing nosocomial infections even higher incidence rate than $P$. aeruginosa [3]. Some of these strains found in human digestive tract with low commensal level while some found in refrigerated food products with its psychrotrophic characters [4]. Recently, a specific antigen of was detected in serum of ileal Crohn's disease patient [5]. $P$. fluorescens responsible for causing various human diseases and considered as a pathogenic microorganism. Different antimicrobial combination therapies are preferred by microbiologist to alter its sensitivity but due to their associated side effects, alternate approaches are adopted by healthcare professionals. Among various alternate and complementary therapies, biofield might be a new approach to do such alterations.

Biofield is the name given to the electromagnetic field that permeates and surrounds living organisms. It is the scientifically preferred term for the biologically produced electromagnetic and subtle energy field that provides regulatory and communication functions within the organism. In spite of countless study reports of the effectiveness of biofield therapies [6], there are very few well controlled and peer-reviewed experimental studies [7]. According to law of mass-energy inter-conversion [8], the conversion of mass into energy is well stabilized, but its inversion i.e. energy into mass is not yet proved scientifically. Whenever these electrical signals fluctuate with time, the magnetic field generates as per the Ampere-Maxwell law, and cumulatively known as electromagnetic field. As responses by humans can be accounted for by the placebo effect, these experiments on lower organisms are designed in order to directly test the impact of biofield energy through scientific studies to rule out the placebo effect. It is widely accepted that lyophilization is the most preferred method to store and transport microbial cultures. Therefore, changes in the biochemical and enzymatic characteristics of an organism cannot be possible at this storage condition. Mr. Mahendra Trivedi's biofield 
Page 2 of 5

treatment has been studied significantly and its effects are considerably altered the antibiotic susceptibility and biochemical reactions of microbes against tested antimicrobials [9-11]. However, researchers found significant inhibitory effect of biofield in different cancer cell models [12-14]. It has also shown significantly altered the crystalline and powder characteristics of metals $[15,16]$. In agriculture, biofield treated crops have been reported for a significant change on growth, characteristics and yield of plants [17-19].

There are scanty reports on investigating biofield therapies against microbes. In the present study, impact of biofield treatment on $P$. fluorescens was evaluated and its antimicrobial susceptibility pattern, MIC value, biochemical reactions, and biotype were studied in revived and lyophilized cells of $P$. fluorescens as compared to control.

\section{Material and methods}

P. fluorescens ATCC 49838 (American Type Culture Collection) strains were procured from MicroBioLogics, Inc., USA, in two sets A and $\mathrm{B}$. The antimicrobials and biochemical used in the study were procured from Sigma-Aldrich. Two different sealed packs were stored with proper storage conditions until further use. The antimicrobial susceptibility, biochemical reactions and biotype number were estimated with the help of Microscan Walk-Away system ${ }^{\oplus}$ (Dade Behring Siemens) using NBPC30 panel with respect to control groups.

\section{Study Design}

Two ATCC samples (ATCC A and B) of P. fluorescens were grouped and subjected to biofield treatment. ATCC A sample was revived and divided into two groups (Gr) viz. Gr.I (control) and Gr.II (revived); likewise, ATCC B was labeled as Gr.III (lyophilized). Then group II and III were treated with Mr. Trivedi's biofield energy. Gr.II was assessed on the $5^{\text {th }}$ and $10^{\text {th }}$ days after treatment while Gr.III was assessed on $10^{\text {th }}$ day only. Finally, all the groups (control and treated) were investigated for antimicrobial susceptibility, biochemical reactions pattern and biotyping.

\section{Antimicrobial susceptibility assay}

Antimicrobial susceptibility pattern of $P$. fluorescens was studied using MicroScan Walk-Away using NBPC30 panel as per manufacturer's instructions. The qualitative antimicrobial susceptibility pattern (S: Susceptible, I: Intermediate, and R: Resistant) and minimum inhibitory concentration (MIC) were determined by observing the change in antimicrobial concentration as per Clinical and Laboratory Standards Institute (CLSI) guidelines [20].

\section{Biochemical reaction and biotype number studies}

The biochemical reactions and biotype number followed by organism identification after biofield treatment of $P$. fluorescens were studied using MicroScan Walk-Away ${ }^{\oplus}$ system [21]. Alteration in biochemical reactions patterns after biofield treatment were analyzed using following 33 biochemical such as acetamide, adonitol, arabinose, arginine, cetrimide, cephalothin, citrate, colistin, esculin, hydrolysis, nitrofurantoin, glucose, hydrogen sulfide, indole, inositol, kanamycin, lysine, malonate, melibiose, nitrate, oxidation-fermentation, galactosidase, ornithine, oxidase, penicillin, raffinose, rhaminose, sorbitol, sucrose, tartarate, tryptophan deaminase, tobramycin, urea, and Voges-Proskauer.

\section{Results}

\section{Antimicrobial susceptibility assay}

The data pertaining to the antimicrobial susceptibility tests and details of MIC values were observed and reported in Table 1 and 2 respectively. The result of biofield treatment showed that sensitivity pattern of ceftriaxone and tetracycline converted from I $\rightarrow$ R Gr.II on day 5 and 10. Ceftazidime, ciprofloxacin and piperacillin, converted from $\mathrm{S} \rightarrow \mathrm{R}$ in Gr.II on day 5 and 10 with changes in MIC values as compared to control. Cefotaxime sensitivity pattern changed from $\mathrm{I} \rightarrow$ $\mathrm{R}$ in Gr.II while in cefepime, changed from I $\rightarrow \mathrm{R}$ only at day 10 in Gr.II. Tobramycin sensitivity pattern after treatment converted from $\mathrm{S}$ $\rightarrow$ I with altered MIC value on day 5 while $S \rightarrow R$ on day 10 in Gr.II. In case of norfloxacin, change in MIC value was reported greater than 8 $\mu \mathrm{g} / \mathrm{mL}$ in Gr.II as compared with control. Rest of tested antimicrobials did not showed any change in susceptibility pattern and MIC values after biofield treatment as compared to control (Table 2).

\begin{tabular}{|c|c|c|c|c|c|}
\hline \multirow{3}{*}{ S. No. } & \multirow{3}{*}{ Antimicrobial } & \multicolumn{4}{|c|}{ Type of Response } \\
\hline & & \multirow{2}{*}{$\begin{array}{c}\text { Gr.I } \\
\text { Control }\end{array}$} & \multicolumn{2}{|c|}{ Gr.II } & \multirow{2}{*}{$\begin{array}{c}\text { Gr.III } \\
\text { Day } 10\end{array}$} \\
\hline & & & Day 5 & Day 10 & \\
\hline 1 & Amikacin & $\mathrm{s}$ & $\mathrm{s}$ & $\mathrm{s}$ & $\mathrm{s}$ \\
\hline 2 & Amoxicillin/K-clavulanate & - & - & - & - \\
\hline 3 & Ampicillin/Sulbactam & - & - & - & - \\
\hline 4 & Aztreonam & $\mathrm{R}$ & $\mathrm{R}$ & $\mathrm{R}$ & $\mathrm{R}$ \\
\hline 5 & Cefepime & 1 & 1 & $\mathrm{R}$ & 1 \\
\hline 6 & Cefotaxime & 1 & $\mathrm{R}$ & $\mathrm{R}$ & 1 \\
\hline 7 & Ceftazidime & $\mathrm{s}$ & $\mathrm{R}$ & $\mathrm{R}$ & $\mathrm{s}$ \\
\hline 8 & Ceftriaxone & 1 & $\mathrm{R}$ & $\mathrm{R}$ & 1 \\
\hline 9 & Chloramphenicol & $\mathrm{R}$ & $\mathrm{R}$ & $\mathrm{R}$ & $\mathrm{R}$ \\
\hline 10 & Ciprofloxacin & $\mathrm{s}$ & $\mathrm{R}$ & $\mathrm{R}$ & $\mathrm{s}$ \\
\hline 11 & Gentamicin & $\mathrm{s}$ & $\mathrm{s}$ & $\mathrm{s}$ & $s$ \\
\hline 12 & Imipenem & $\mathrm{s}$ & $\mathrm{s}$ & $\mathrm{s}$ & $\mathrm{s}$ \\
\hline 13 & Levofloxacin & $\mathrm{s}$ & $\mathrm{s}$ & $\mathrm{s}$ & $\mathrm{s}$ \\
\hline 14 & Meropenem & $\mathrm{s}$ & $\mathrm{s}$ & $\mathrm{s}$ & $\mathrm{s}$ \\
\hline 15 & Norfloxacin & - & - & - & - \\
\hline 16 & Piperacillin/Tazobactam & $\mathrm{s}$ & $\mathrm{s}$ & $\mathrm{s}$ & $\mathrm{s}$ \\
\hline 17 & Piperacillin & $\mathrm{s}$ & $\mathrm{R}$ & $\mathrm{R}$ & $\mathrm{s}$ \\
\hline 18 & Tetracycline & 1 & $\mathrm{R}$ & $\mathrm{R}$ & $\mathrm{s}$ \\
\hline 19 & Ticarcillin/K-Clavulanate & $\mathrm{R}$ & $\mathrm{R}$ & $\mathrm{R}$ & $\mathrm{R}$ \\
\hline 20 & Tobramycin & $s$ & I & $\mathrm{R}$ & $\mathrm{s}$ \\
\hline \multirow{2}{*}{21} & Trimethoprim/ & \multirow{2}{*}{$\mathrm{R}$} & \multirow{2}{*}{$\mathrm{R}$} & \multirow{2}{*}{$\mathrm{R}$} & \multirow{2}{*}{$\mathrm{R}$} \\
\hline & Sulfamethoxazole & & & & \\
\hline
\end{tabular}


Citation: Trivedi MK, Patil S, Shettigar H, Gangwar M, Jana S (2015) Antimicrobial Sensitivity Pattern of Pseudomonas fluorescens after Biofield

Page 3 of 5

R: Resistant; I: Intermediate; S: Susceptible; '-': Not reported; Gr: group

Table 1: Effect of biofield treatment on antimicrobial susceptibility of P. fluorescens

\begin{tabular}{|c|c|c|c|c|c|}
\hline \multirow{3}{*}{$\begin{array}{l}\text { S. } \\
\text { No. }\end{array}$} & \multirow{3}{*}{ Antimicrobial } & \multicolumn{4}{|c|}{ MIC } \\
\hline & & \multirow{2}{*}{$\begin{array}{c}\text { Gr.I } \\
\text { Control }\end{array}$} & \multicolumn{2}{|c|}{ Gr.II } & \multirow{2}{*}{$\begin{array}{c}\text { Gr.III } \\
\text { Day } 10\end{array}$} \\
\hline & & & Day 5 & Day 10 & \\
\hline 1 & Amikacin & $\leq 16$ & $\leq 16$ & $\leq 16$ & $\leq 16$ \\
\hline 2 & Amoxicillin/K-clavulanate & $>16 / 8$ & $>16 / 8$ & $>16 / 8$ & $>16 / 8$ \\
\hline 3 & Ampicillin/Sulbactam & $>16 / 8$ & $>16 / 8$ & $>16 / 8$ & $>16 / 8$ \\
\hline 4 & Ampicillin & $>16$ & $>16$ & $>16$ & $>16$ \\
\hline 5 & Aztreonam & $>16$ & $>16$ & $>16$ & $>16$ \\
\hline 6 & Cefazolin & $>16$ & $>16$ & $>16$ & $>16$ \\
\hline 7 & Cefepime & 16 & 16 & $>16$ & 16 \\
\hline 8 & Cefotaxime & 32 & $>32$ & $>32$ & 32 \\
\hline 9 & Cefotetan & $>32$ & $>32$ & $>32$ & $>32$ \\
\hline 10 & Cefoxitin & $>16$ & $>16$ & $>16$ & $>16$ \\
\hline 11 & Ceftazidime & $\leq 8$ & $>16$ & $>16$ & $\leq 8$ \\
\hline 12 & Ceftriaxone & 32 & $>32$ & $>32$ & 32 \\
\hline 13 & Cefuroxime & $>16$ & $>16$ & $>16$ & $>16$ \\
\hline 14 & Cephalothin & $>16$ & $>16$ & $>16$ & $>16$ \\
\hline 15 & Chloramphenicol & $>16$ & $>16$ & $>16$ & $>16$ \\
\hline 16 & Ciprofloxacin & $\leq 1$ & $>2$ & $>2$ & $\leq 1$ \\
\hline 17 & Gatifloxacin & $\leq 2$ & $\leq 2$ & $\leq 2$ & $\leq 2$ \\
\hline 18 & Gentamicin & $\leq 4$ & $\leq 4$ & $\leq 4$ & $\leq 4$ \\
\hline 19 & Imipenem & $\leq 4$ & $\leq 4$ & $\leq 4$ & $\leq 4$ \\
\hline 20 & Levofloxacin & $\leq 2$ & $\leq 2$ & $\leq 2$ & $\leq 2$ \\
\hline 21 & Meropenem & $\leq 4$ & $\leq 4$ & $\leq 4$ & $\leq 4$ \\
\hline 22 & Moxifloxacin & 4 & 4 & 4 & 4 \\
\hline 23 & Nitrofurantoin & $>64$ & $>64$ & $>64$ & $>64$ \\
\hline 24 & Norfloxacin & $\leq 4$ & $>8$ & $>8$ & $\leq 4$ \\
\hline 25 & Piperacillin/Tazobactam & $\leq 16$ & $\leq 16$ & $\leq 16$ & $\leq 16$ \\
\hline 26 & Piperacillin & $\leq 16$ & $>64$ & $>64$ & $\leq 16$ \\
\hline 27 & Tetracycline & 8 & $>8$ & $>8$ & $\leq 4$ \\
\hline 28 & Ticarcillin/K-Clavulanate & $>64$ & $>64$ & $>64$ & $>64$ \\
\hline 29 & Tobramycin & $\leq 4$ & 8 & $>8$ & $\leq 4$ \\
\hline 30 & $\begin{array}{c}\text { Trimethoprim/ } \\
\text { Sulfamethoxazole }\end{array}$ & $>2 / 38$ & $>2 / 38$ & $>2 / 38$ & $>2 / 38$ \\
\hline
\end{tabular}

\section{MIC values are presented in $\mu \mathrm{g} / \mathrm{mL}$; Gr: Group}

Table 2: Minimum inhibitory concentration (MIC) of $P$. fluorescens for tested antimicrobials

\section{Biochemical study}

Biochemical tests denoted with codes are summarized in Table 3. Results showed positive reactions (i.e. (-) negative to (+) positive) in case of malonate, melibiose, nitrate, galactosidase, ornithine, raffinose, sorbitol, sucrose, tobramycin, and Voges-Proskauer on day 5 and 10 in Gr II on both days with respect to control. Arabinose, colistin, and rhaminose showed negative reactions (i.e. $(+)$ positive to (-) negative) in Gr II only on day 10 as compared to control. Arginine was converted into positive to negative reaction in Gr.III and in Gr.II at day 5 only. Cetrimide showed negative reaction in Gr.III as compared to control. Glucose showed positive reaction at day 10 in Gr.II and Gr.III as compared to control.

\begin{tabular}{|c|c|c|c|c|c|c|}
\hline \multirow{2}{*}{ S. } & \multirow{2}{*}{ No. } & \multirow{2}{*}{ Code } & Biochemical & Gr.I & \multicolumn{3}{|c|}{ Gr.II } & Gr.III \\
\cline { 3 - 7 } & & & Control & Day 5 & Day 10 & Day 10 \\
\hline 1 & ACE & Acetamide & - & - & - & - \\
\hline 2 & ADO & Adonitol & - & - & - & - \\
\hline 3 & ARA & Arabinose & - & - & + & - \\
\hline 4 & ARG & Arginine & + & - & + & - \\
\hline 5 & CET & Cetrimide & + & + & + & - \\
\hline 6 & CF8 & Cephalothin & + & + & + & + \\
\hline 7 & CIT & Citrate & + & + & + & + \\
\hline 8 & CL4 & Colistin & - & - & + & - \\
\hline 9 & ESC & Esculin hydrolysis & - & - & - & - \\
\hline 10 & FD64 & Nitrofurantoin & + & + & + & + \\
\hline 11 & GLU & Glucose & - & - & + & + \\
\hline 12 & H2S & Hydrogen sulfide & - & - & - & - \\
\hline 13 & IND & Indole & - & - & - & - \\
\hline 14 & INO & Inositol & - & - & - & - \\
\hline 15 & K4 & Kanamycin & + & + & + & + \\
\hline 16 & LYS & Lysine & - & - & - & - \\
\hline 17 & MAL & Malonate & - & + & + & - \\
\hline 18 & MEL & Melibiose & - & + & + & - \\
\hline 19 & NIT & Nitrate & - & + & + & - \\
\hline 20 & OF/G & Fermentation & + & + & + & + \\
\hline & ONP & Galactosidase & - & + & + & - \\
\hline & & Ornithine & - & + & + & - \\
\hline
\end{tabular}




\begin{tabular}{|c|c|c|c|c|c|c|}
\hline 23 & OXI & Oxidase & + & + & + & + \\
\hline 24 & P4 & Penicillin & + & + & + & + \\
\hline 25 & RAF & Raffinose & - & + & + & - \\
\hline 26 & RHA & Rhaminose & - & - & + & - \\
\hline 27 & SOR & Sorbitol & - & + & + & - \\
\hline 28 & SUC & Sucrose & - & + & + & - \\
\hline 29 & TAR & Tartarate & - & - & - & - \\
\hline 30 & TDA & Tryptophan & - & - & - & - \\
\hline 31 & TO4 & Tobramycin & - & + & + & - \\
\hline 32 & URE & Urea & - & - & - & - \\
\hline 33 & VP & Voges-Proskauer & - & + & + & - \\
\hline
\end{tabular}

Table 3: Effect of biofield treatment on biochemical reactions of $P$. fluorescens

\section{Study of Biotype number}

Biochemical tests result revealed a change in biotype number in Gr.II on day 5 (34101173) and day 10 (77103177, a very rare biotype) as compared to control (02041722). In Lyophilized treated group showed a change, not only in biotype number (40000043), but also changed to new species. Organism identified as Vibrio fluvialis (Gr.III, day 10) and Enterobacter cloacae (GrII, day 10) with respect to control (Table 4).

\begin{tabular}{|c|c|c|c|c|}
\hline \multirow{2}{*}{ Feature } & Gr.I & \multicolumn{2}{|c|}{ Gr.II } & Gr.III \\
\cline { 2 - 5 } & Control & Day 5 & Day 10 & Day 10 \\
\hline $\begin{array}{c}\text { Biotype } \\
\text { number }\end{array}$ & 02041722 & 34101173 & 77103177 & 40000043 \\
\hline $\begin{array}{c}\text { Organism } \\
\text { identification }\end{array}$ & $\begin{array}{c}\text { P. } \\
\text { fluorescens/ } \\
\text { putida }\end{array}$ & P. fluorescens & $\begin{array}{c}\text { Enterobacter } \\
\text { cloacae }\end{array}$ & Vibrio fluvialis \\
\hline
\end{tabular}

Table 4: Effect of biofield treatment on biotype number of $P$. fluorescens

\section{Discussion}

Due to the high frequency of antimicrobial resistance among clinical isolates of $P$. fluorescens, it causes serious problems in the choice of an appropriate antimicrobials in the past 15 years. $P$. fluorescens was isolated in bottled water and causing bacteremia and pseudo bacteremia in immunocompromised patients in hospitals from contamination of disinfectants and blood collecting tubes [22]. Although $P$. fluorescens considered to be non-pathogenic to humans, but recent reports on clinical strains of $P$. fluorescens have cause serious health problems [23-25] which require some alternative treatment approach.

Ceftazidime is the choice of drug used against $P$. fluorescens infection, either alone or in combination with gentamicin. $P$. fluorescens was highly sensitive to kanamycin, tetracycline, and chloramphenicol at very low concentration [26]. This study results showed that biofield treatment has an alteration in sensitivity pattern of selected antimicrobials mentioned in Table 1 with respect to control. Ceftriaxone, tetracycline, ceftazidime, ciprofloxacin, piperacillin, cefotaxime, and tobramycin showed an alteration in sensitivity pattern and MIC values after biofield treatment with respect to control (Tables 1 and 2).

Based on literatures, important biochemical characteristics test of Pseudomonas species gives negative reaction in case of VogesProskauer, indole, and methyl red, while positive reaction in catalase test. While some species i.e. P. fluorescens show a positive oxidase test [27]. In this experiment, results of biochemical reactions showed positive reaction in arginine, cetrimide while negative reaction in Voges-Proskauer, arabinose, colistin, rhaminose, malonate, melibiose, nitrate, galactosidase, ornithine, raffinose, sorbitol, sucrose, and tobramycin. After biofield treatment, results showed altered biochemical reactions which suggest that biofield treatment might cause some changes at enzymatic or metabolic pathway leading to significant phenotypic alteration in $P$. fluorescens. Biotyping makes use of the pattern of metabolic activities expressed by an isolate, colonial morphology and environmental tolerances. In this experiment, biotyping was performed using automated system and found a significant changed in the biotype number and identified a new species in treated groups, and organism identified as Enterobacter cloacae (Gr.II, day 10) and Vibrio fluvialis (Gr.III, day 10) with respect to control, $P$. fluorescens. Hence, results support that biofield treatment has altered the biotype number and shown a significant change of organism but additional molecular methods are further required to study these changes.

In biomedical health care system, biofield therapies are very popular and claims to enhance human well-being and other metabolic pathways [28-30]. In microbiology, biofield treatment altered the phenotypic characteristics of microorganism, results supposed the involvement of electromagnetic field that acts on molecular level at cell receptor protein. Biofield alteration, modifies ligand-receptor interaction which causes alteration in phenotypic characters. Research reports suggest that extremely low frequency electromagnetic fields (ELF-EMF) could alter transmembrane $\mathrm{Ca}^{2+}$ concentration which causes damage and developmental defects in different organs [31,32]. ELF-EMF also induce phosphorylation of receptor protein in T-cell membrane [33]. Hence, it is assumed that biofield treatment made some alteration at enzymatic or genetic level which manifested in phenotypic alteration. Experimental data showed that, biofield treatment induces changes in susceptibility pattern of antimicrobials, biochemical reactions, MIC values, and biotype number. Biofield treatment is cost effective and has been experimentally demonstrated an alternative approach to study the alteration in sensitivity pattern of microorganism.

\section{Conclusion}

Study results conclude that biofield treatment has altered the susceptibility pattern and MIC value of $P$. fluorescens. Biochemical study revealed a significant changes in most of the biochemical reactions after biofield treatment. Biotype study showed a significant change in number and species of microorganism after biofield treatment as compared to control. 


\section{Acknowledgement}

Authors gratefully acknowledged the whole team of PD Hinduja National Hospital and MRC, Mumbai, Microbiology Lab for their support.

\section{Conflict of Interest}

The authors declare that they have no competing interests.

\section{References}

1. Pittman M (1953) A study of bacteria implicated in transfusion reactions and of bacteria isolated from blood products. J Lab clin Med 42: 273-288.

2. Madi A, Lakhdari O, Blottière HM, Guyard-Nicodeme M, Le Roux K, et al. (2010) The clinical Pseudomonas fluorescens MFN1032 strain exerts a cytotoxic effect on epithelial intestinal cells and induces Interleukin-8 via the AP-1 signaling pathway. BMC Microbiol 10: 215.

3. Farquhar MG, Palade GE (1963) Junctional complexes in various epithelia. J Cell Biol 17: 375-412.

4. Rajmohan S, Dodd CE, Waites WM (2002) Enzymes from isolates of Pseudomonas fluorescens involved in food spoilage. J Appl Microbiol 93: 205-213.

5. Sutton CL, Kim J, Yamane A, Dalwadi H, Wei B, et al. (2000) Identification of a novel bacterial sequence associated with Crohn's disease. Gastroenterology 119: 23-31.

6. Benor DJ (2002) Energy medicine for the internist. Med Clin North Am 86: 105-125.

7. Jonas WB, Crawford CC (2003) Science and spiritual healing: a critical review of spiritual healing, "energy" medicine, and intentionality. Altern Ther Health Med 9: 56-61.

8. Einstein A (1905) Does the inertia of a body depend upon its energycontent. Ann Phys 18: 639-641.

9. Trivedi MK, Patil S (2008) Impact of an external energy on Staphylococcus epidermis [ATCC-13518] in relation to antibiotic susceptibility and biochemical reactions-an experimental study. J Accord Integr Med 4: 230-235.

10. Trivedi MK, Patil S (2008) Impact of an external energy on Yersinia enterocolitica [ATCC-23715] in relation to antibiotic susceptibility and biochemical reactions: an experimental study. Internet J Alternat Med 6: 13 .

11. Trivedi MK, Bhardwaj Y, Patil S, Shettigar H, Bulbule A (2009) Impact of an external energy on Enterococcus faecalis [ATCC-51299] in relation to antibiotic susceptibility and biochemical reactions-an experimental study. J Accord Integr Med 5: 119-130.

12. Running A (2015) Decreased cortisol and pain in breast cancer: Biofield therapy potential. Evid Based Complement Alternat Med.

13. Yount G, Patil S, Dave U, Alves-dos-Santos L, Gon K, et al. (2013) Evaluation of biofield treatment dose and distance in a model of cancer cell death. J Alternat Complement Med 19: 124-127.

14. Chen KW (2008) Inhibitory effects of bio-energy therapies on cancer growth. World Sci Tech Modern Trad Chin Med 10: 144-152.

15. Dabhade VV, Tallapragada RR, Trivedi MK (2009) Effect of external energy on atomic, crystalline and powder characteristics of antimony and bismuth powders. Bull Mat Sci 32: 471-479.
16. Trivedi MK, Patil S, Tallapragada RM (2012) Thought Intervention through biofield changing metal powder characteristics experiments on powder characterisation at a PM Plant, Springer Berlin Heidelberg. Lecture Notes in Electrical Engineering-Future Control and Automation 173: 247-252.

17. Shinde V, Sances F, Patil S, Spence A (2012) Impact of biofield treatment on growth and yield of lettuce and tomato. Austral J Bas App Sci 6: 100-105.

18. Sances F, Flora E, Patil S, Spence A, Shinde V (2013) Impact of biofield treatment on ginseng and organic blueberry yield. AGRIVITA J Agri Sci 35: 22-29.

19. Lenssen AW (2013) Biofield and fungicide seed treatment influences on soybean productivity, seed quality and weed community. Agric J 8: 138-143.

20. Fader RC, Weaver E, Fossett R, Toyras M, Vanderlaan J, et al. (2013) Multilaboratory study of the biomic automated well-reading instrument versus MicroScan WalkAway for reading MicroScan antimicrobial Susceptibility and identification panels. J Clin Microbiol 51: 1548-1554.

21. Gomaa FM, Tawakol WM, Abo El-Azm FI (2014) Phenotypic and genotypic detection of some antimicrobial resistance mechanisms among multidrug-resistant Acinetobacter baumannii isolated from immunocompromised patients in Egypt. Egypt J Med Microbiol 23: 99-111.

22. Wong V, Levi K, Baddal B, Turton J, Boswell T (2011) Spread of Pseudomonas fluorescens due to contaminated drinking water in a bone marrow transplant unit. J Clin Microbiol 49: 2093-2096.

23. Chapalain A, Rossignol G, Lesouhaitier O, Merieau A, Gruffaz C, et al (2007) Comparative study of 7 fluorescent pseudomonad clinical isolates. Canad J Microbiol 54: 19-27.

24. Picot L, Abdelmoula SM, Merieau A, Lerouxb P, Cazina L, et al. (2001) Pseudomonas fluorescens as a potential pathogen: adherence to nerve cells. Microb \& Infect 3: 985-995.

25. Madi A, Svinareff P, Orange N, Feuilloley MG, Connil N (2010) Pseudomonas fluorescens alters epithelial permeability and translocates across Caco-2/TC7 intestinal cells. Gut Pathog 2: 1-8.

26. Morgan A (2014) The synergistic effect of gentamicin and ceftazidime against Pseudomonas fluorescens. Bioscience Horizons 7: hzu007.

27. Phillip I (1969) Identification of Pseudomonas aeruginosa in the clinical laboratory. J Med Microbiol 2: 9-16.

28. Giasson M, Bouchard L (1998) Effect of therapeutic touch on the wellbeing of persons with terminal cancer. J Holist Nurs 16: 383-398.

29. Peck SD (1998) The efficacy of therapeutic touch for improving functional ability in elders with degenerative arthritis. Nurs Sci Q 11: 123-132.

30. Turner JG, Clark AJ, Gauthier DK, Williams M (1998) The effect of therapeutic touch on pain and anxiety in burn patients. J Adv Nurs 28: $10-20$.

31. Oschman JL (2002) Clinical aspects of biological fields: an introduction for health care professionals. J Bodyw Mov Ther 6: 117-125.

32. Lindstrom E, Hansson M, Lundgren E (1998) Analysis of the T cell activation signaling pathway during ELF magnetic field exposure, p56lck and [Ca2+]i-measurements. Bioeletrochem Bioenerg 46: 129-137.

33. Lindstrom E, Still M, Mattsson M, Mild KH, Luben RA (2000) ELF magnetic fields initiate protein tyrosine phosphorylation of the $\mathrm{T}$ cell receptor complex. Bioelectrochemistry 53: 73-78. 